\title{
Model Pembelajaran Kontekstual Meningkatkan Hasil Belajar Matematika Siswa Kelas V Sekolah Dasar
}

\author{
Panji Setiawan ${ }^{1 *}$, I Dewa Nyoman Sudana² iD \\ 1,2 Programstudi PPG PGSD Prajabatan, Universitas Pendidikan Ganesha, Singaraja, Indonesia \\ *Corresponding author: panjiriflame646@gmail.com
}

\section{Abstrak}

Rendahnya hasil belajar matematika siswa dikarenakan kurangnya pemahaman siswa terhadap materi pelajaran yang disampaikan oleh guru dan dalam prose pembelajaran guru belum menerapkan model pembelajaran yang inovatif. Penelitian ini bertujuan menganalisis model pembelajaran kontekstual terhadap hasil belajar matematika siswa kelas V sekolah dasar. Penelitian ini merupakan penelitian tindakan kelas yang terdiri dari dua siklus. Tiap siklus mempunyai tahapan diantaranya tahap perencanaan tindakan, tahap pelaksanaan, tahap observasi, dan tahap refleksi. Dalam penelitian ini digunakan model pembelajaran kontekstual. Subjek penelitian ini adalah siswa kelas V yang berjumlah 38 orang, terdiri dari 14 laki-laki dan 24 perempuan. Metode pengumpulan data yang digunakan dalam penelitian ini adalah observasi dan tes pilihan ganda. Analisis data dalam penelitian ini menggunakan teknik analisis deskriptif kualitatif dan kuantitatif. Hasil penelitian pada siklus I terjadi peningkatan hasil belajar matematika siswa dengan nilai rata-rata adalah 78,42 dan persentase ketuntasan klasikal 92\%. Hasil penelitian pada siklus II mengalami peningkatan menjadi 82,94 dengan persentase ketuntasan klasikal $100 \%$. Hal ini menunjukkan bahwa target penelitian telah tercapai pada siklus dua yaitu nila rata-rata hasil belajar siswa berdasarkan PAP masuk dalam kategori tinggi. Berdasarkan hasil penelitian tersebut, dapat disimpulkan bahwa penggunaan model pembelajaran kontekstual dapat meningkatkan hasil belajar matematika siswa kelas V sekolah dasar.

Kata kunci: Pembelajaran Kontekstual, Hasil Belajar Matematika

\section{Abstract}

The low achievement of students' mathematics learning is due to the lack of students' understanding of the subject matter presented by the teacher and in the learning process, the teacher has not implemented an innovative learning model. This study aims to analyze the contextual learning model on the mathematics learning outcomes of fifth-grade elementary school students. This research is a classroom action research that consists of two cycles. Each cycle has stages including the action planning stage, the implementation stage, the observation stage, and the reflection stage. In this study, a contextual learning model was used. The subjects of this study were 38 students of class V, consisting of 14 boys and 24 girls. Data collection methods used in this study were observation and multiple-choice tests. Data analysis in this study used qualitative and quantitative descriptive analysis techniques. In the results of the research in the first cycle, there was an increase in students' mathematics learning outcomes with an average value of 78.42 and a classical mastery percentage of $92 \%$. The results of the research in the second cycle increased to 82.94 with a percentage of $100 \%$ classical completeness. This shows that the research target has been achieved in cycle two, namely the average value of student learning outcomes based on the PAP is in the high category. Based on the results of this study, it can be concluded that the use of contextual learning models can improve mathematics learning outcomes for fifth-grade elementary school students.

Keywords: contextual learning, Mathematics Learning outcomes

\section{INTRODUCTION}

Salah satu mata pelajaran yang penting adalah Matematika. Matematika sangat erat kaitannya dengan kehidupan. Matematika bukanlah pengetahuan yang dapat sempurna karena dirirnya sendiri, tetapi keberadaannya untuk membantu manusia memahami, menguasai permasalahan sosial, ekonomi dan alam (Masykur et al., 2017; Ningsih, 2016). Oleh karena itu, dapat dikatakan matematika berguna bagi tiap sendi-sendi kehidupan manusia. Matematika adalah pengetahuan yang berkaitan dengan berbagai struktur abstrak dan hubungan struktur-struktur tersebut sehingga terorganisasi dengan baik. Matematika merupakan suatu ilmu yang mempelajari tentang konsep-konsep logika yang representasinya menggunakan symbol, pola, dan hubungan yang berfungsi untuk membantu manusia

$\begin{array}{ll}\text { History: } & \\ \text { Received } & \text { : June 24, } 2018 \\ \text { Revised } & \text { : July 02, } 2018 \\ \text { Accepted } & \text { : January 02, } 2021 \\ \text { Published } & \text { : May 25, 2021 }\end{array}$


memahami, menguasai permasalahan sosial, ekonomi, dan alam (Azhari \& Irfan, 2018; Setyadi \& Qohar, 2017). Matematika perlu diberikan kepada semua siswa khususnya di sekolah dasar untuk membekali siswa dengan kemampuan berpikir logis, analitis, sistematis, kritis, dan kreatif, serta kemampuan bekerjasama (Adirakasiwi \& Warmi, 2018; Riski Juniarti1 et al., 2020; Zairisma et al., 2020). Kompetensi tersebut diperlukan agar siswa dapat memiliki kemampuan memperoleh, mengelola, dan memanfaatkan informasi untuk menghadapi keadaan yang selalu berubah, dan kompetitif.

Namun berdasarkan hasil observasi yang dilakukan ditemukan bahwa terdapat masalah dalam hasil belajar matematika siswa kelas $\mathrm{V}$ yang rendah. Hal ini dibuktikan dari hasil rekap nilai matematika siswa pada semester I. Semiblan orang siswa secara individu masuk kategori kurang dan satu orang siswa tidak mencapai KKM sekolah. Data lain berdasarkan hasil wawancara, diketahui bahwa rendahnya hasil belajar matematika kelas $\mathrm{V}$ adalah rendahnya pemahaman siswa terhadap materi pelajaran yang disampaikan oleh guru. Dalam penyampaian materi, guru tidak menggunakan model pembelajaran dengan pendekatan saintifik yang menyebabkan ada siswa yang terlihat kurang aktif dalam kegiatan pembelajaran. Penggunaan model pembelajaran diperlukan untuk mengaktifkan siswa dalam kegiatan pembelajaran sehingga siswa dapat menkonstruksi dan menemukan sendiri konsep dari materi pelajaran yang disampaikan guru.

Berdasarkan permasalahan tersebut, jika dibiarkan maka akan menimbulkan dampak buruk bagi proses pembelajaran di sekolah tersebut. Maka, solusi yang dapat dilakukan adalah dengan menerapkan pembelajaran dengan model pembelajaran yang dapat membuat siswa terlibat aktif dalam proses pembelajaran. Salah satu model yang dapat dijadikan solusi adalah model pembelajaran kontekstual. Model pembelajaran ini menghubungkan konsep pelajaran dengan kehidupan siswa. Dalam kegiatan pembelajaran kontekstual, siswa menkonstruksi dan menemukan sendiri konsep atau pengetahuan yang diterima. Pembelajaran kontekstual memiliki tujuh prinsip yang berorientasi pada siswa yaitu konstruktivisme, inkuiri, bertanya, masyarakat belajar (berkelompok), pemodelan, refleksi siswa, dan penilaian autentik (Mahendrawan et al., 2014; Rahayu, 2019; Ramdani, 2018).

Pembelajaran kontekstual merupakan konsep belajar yang dapat membantu guru mengaitkan antara materi yang diajarkannya dengan situasi dunia nyata siswa dan mendorong siswa membuat hubungan antar pengetahuan yang dimilikinya dengan penerapannya dalam kehidupan mereka sebagai anggota keluarga dan masyarakat (Primayana et al., 2019; Setiawan \& Sudana, 2018). Dengan pembelajaran kontekstual proses pembelajaran diharapkan berlangsung alamiah dalam bentuk kegiatan siswa untuk bekerja dan mengalami, bukan transfer pengetahuan dari guru ke siswa. Strategi pembelajaran lebih dipentingkan dari pada hasil. Dalam konteks itu siswa perlu mengerti apa makna belajar, apa manfaatnya, mereka dalam status apa dan bagaimana cara mencapainya. Mereka akan menyadari bahwa yang mereka pelajari berguna bagi hidupnya. Dengan demikian mereka mempelajari sesuatu yang bermanfaat bagi dirinya dan berupaya menggapainya. Dalam upaya itu, mereka memerlukan guru sebagai pengarah dan pembimbing. Untuk menciptakan kondisi tersebut strategi belajar yang tidak mengharuskan siswa menghafal fakta-fakta, tetapi sebuah strategi yang mendorong siswa mengkontruksi pengetahuan dibenak mereka sendiri.

Beberapa penelitian yang relevan dengan penelitian ini adalah penelitian yang dilakukan oleh (Rahayu, 2019) yang menemukan bahwa pengggunaan model pembelajaran Kontekstual yang dilaksanakan sesuai skenario dapat meningkatkan hasil belajar materi bangun datar pada siswa kelas III SD. Kemudian penelitian yang dilakukan oleh (Lestari, 2019) menemukan bahwa terdapat perbedaan hasil belajar Matematika antara siswa yang mengikuti pembelajaran kontekstual dengan siswa yang mengikuti pembelajaran konvensional serta terdapat kontribusi kemampuan numerik dan kemampuan verbal terhadap 
hasil belajar Matematika. Penelitian lain juga dilakukan dan menemukan bahwa penggunaan model pembelajaran kontekstual dapat meningkatkan hasil belajar matematika siswa kelas 5 SD (Setiawan \& Sudana, 2018). Tujuan penelitian ini menganalisis model pembelajaran kontekstual terhadap hasil belajar matematika siswa kelas V sekolah dasar.

\section{MATERIALS AND METHODS}

Penelitian ini merupakan Penelitian Tindakan Kelas. Penelitian ini dilaksanakan dengan model siklus dengan langkah-langkah dalam tiap siklus diantaranya; tahap perencanaan tindakan, pelaksanaan, pengamatan/ observasi, dan refleksi yang kemudian apabila target penelitian belum tercapai pada siklus pertama maka penelitian akan dilanjutkan ke siklus selanjutnya ikuti dengan perencanaan ulang pada siklus kedua, dan seterusnya (Arikunto, 2013). Alur PTK dapat dilihat pada Gambar 1.

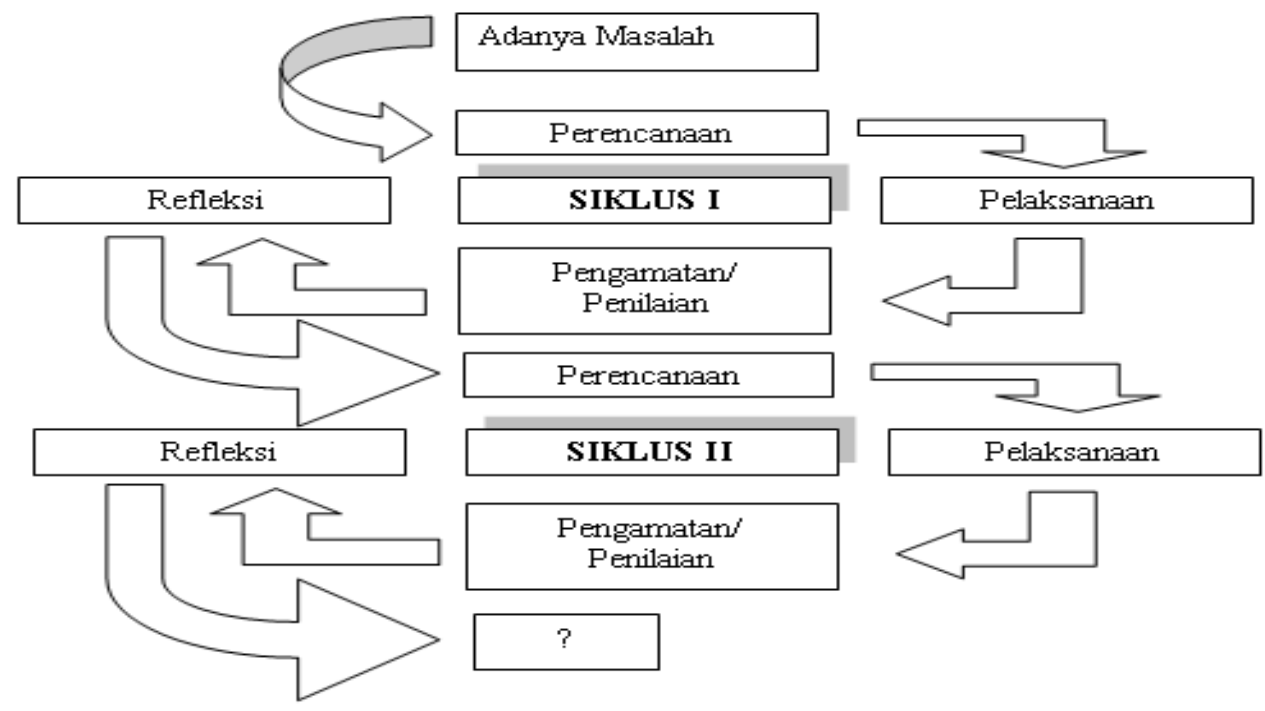

Gambar 1. Alur PTK

Penelitian ini dilaksanakan di kelas V SDN 4 Kaliuntu Kelurahan Kaliuntu Kecamatan Buleleng pada tanggal 3 sampai 17 April 2018. Pelaksanaan kegiatan tiap siklus penelitian ini dialokasikan dua kali pertemuan. Subjek penelitian ini adalah siswa kelas 5 SDN 4 Kaliuntu yang berjumlah 38 orang, terdiri dari 14 laki-laki dan 24 perempuan. Metode pengumpulan data yang digunakan dalam penelitian ini adalah observasi dan tes piluhan ganda. Observasi atau pengamatan bertujuan untuk menilai cara mengajar guru dalam menerapkan model pembelajaran kontekstual serta mengamati kegiatan belajar siswa selama penerapan model pembelajaran kontekstual dengan menggunakan lembar observasi yang telah disiapkan sebelumnya. Sedangkan tes tulis berupa pilihan ganda yang akan dilaksanakan tiap akhir siklus untuk mengetahui peningkatan hasil belajar siswa setelah diterapkannya model pembelajaran kontekstual. Analisis data dalam penelitian ini menggunakan teknik analisis deskriptif kualitatif dan kuantitatif. Analisis data secara kualitatif digunakan untuk menganalisis data hasil observasi. Sedangkan analisis data deskriptif kuantitatif digunakan untuk menganalisa data kuantitatif, seperti hasil tes.

\section{RESULTS AND DISCUSSION}

Penelitian tindakan kelas ini dilaksanakan dengan tujuan menganalisis model pembelajaran kontekstual terhadap hasil belajar matematika siswa. Kegiatan penelitian ini 
dilaksanakan selama dua siklus. Kegiatan pembelajaran disertai evaluasi pembelajaran tiap siklus mempunyai alokasi waktu enam jam pelajaran yang terbagi menjadi dua pertemuan.

Siklus pertama terdiri atas beberapa tahap yaitu tahap perencanaan tindakan, pelaksanaan, pengamatan/ observasi, dan refleksi. Berdasarkan hasil observasi aktivitas belajar siswa pada siklus I diperoleh jumlah skor rata-rata 71 dari nilai maksimal 100 yang masuk dalam kategori baik, sedangkan hasil observasi aktivitas guru diperoleh rata-rata skor 72 dari nilai maksimal 80 yang masuk dalam kategori baik.

Pada siklus I tedapat beberapa kekurangan yang perlu diperbaiki dalam kegiatan pembelajaran khususnya kekurangan dari segi keaktifan dan kedisiplinan siswa. Masih banyak siswa yag terlihat kurang aktif dalam kegiatan pembelajaran baik secara individu maupun kelompok. Hal ini disebabkan karena guru kurang mampu memberikan motivasi bagi siswa. Oleh karena itu guru harus mampu memberikan motivasi belajar bagi siswa serta mengoptimalkan penggunaan model pembelajaran kontekstual untuk menigkatkan keaktifan siswa dalam proses pembelajaran. Selain itu, guru harus mampu memberikan bimbingan dan arahan bagi setiap siswa yang memiliki masalah kedisiplinan dan motivasi belajara yang rendah.

Setelah dilaksanakan evaluasi pembelajaran pada siklus I, dapat diketahui bahwa nilai rata-rata hasil belajar siswa adalah 78,42, dimana 35 siswa tuntas dengan ketuntasan klasikal 92\%. Dari data tersebut, dapat diketahui bahwa nilai rata-rata hasil belajar siswa belum masuk kategori tinggi atau di atas 80 sehingga dapat disimpulkan bahwa target pada siklus I belum tercapai. Peneliti ingin meningkatkan nilai rata-rata hasil belajar siswa, maka dari itu peneliti melanjutkan penelitian ke siklus II.

Tahapan penelitian pada siklus II sama dengan siklus pertama, akan tetapi dalam kegiatan pembelajarannya dilakukan beberapa perbaikan berdasarkan kekurangan pada siklus pertama. Dalam memberikan motivasi, guru mengaitkan materi pelajaran dengan kehidupan serta menjelaskan akibat dan manfaat dari materi pelajaran dalam kehidupan sehari-hari siswa. Selain itu guru juga memberikan reward berupa bintang bagi siswa yang aktif atau berkelakuan baik. Hal ini membuat siswa terlihat lebih antusias dalam kegiatan belajar. Masalah pengendalian kelas telah mampu diatasi oleh guru dengan cara membuat aturan diskusi serta memberikan tambahan poin bagi siswa yang disiplin dan memberikan hukuman berupa pengurangan poin/ bintang bagi siswa yang tidak disiplin.

Pada siklus kedua terjadi perubahan kearah yang lebih baik dari segi aktivitas dan hasil belajar siswa. Skor rata-rata aktivitas belajar siswa dan aktivitas mengajar guru mengalami peningkatan. Skor aktivitas siswa adalah 88 yang masuk kategori aktif, sedangkan skor aktivitas guru adalah 84 yang masuk kategori sangat baik. Rata-rata hasil belajar siswa juga mengalami peningkatan menjadi 82,94 . Dari 38 siswa, seluruhnya dinyatakan tuntas sehingga persentase ketuntasan pada siklus kedua menjadi $100 \%$.

Berdasarkan data pada siklus II, dapat diketahui bahwa target nilai rata-rata hasil belajar siswa telah tercapai yaitu 82,94, masuk dalam kategori tinggi (lebih dari 80). Data rekapitulasi pelaksanaan siklus I dan siklus II dapat dilihat pada Tabel 1.

Tabel 1. Data Rekapitulasi Pelaksanaan Siklus I dan Siklus II

\begin{tabular}{ccccccc}
\hline \multirow{2}{*}{ Siklus } & \multicolumn{2}{c}{ Aktivitas Siswa } & \multicolumn{2}{c}{ Aktivitas Guru } & \multicolumn{2}{c}{ Hasil Belajar } \\
\cline { 2 - 6 } & Rata-Rata & Kategori & Rata-Rata & Kategori & Rata-Rata & $\begin{array}{c}\text { Ketuntasan } \\
\text { Klasikal }\end{array}$ \\
\hline 1 & 71 & Baik & 72 & Baik & 78,42 & $92 \%$ \\
2 & 88 & $\begin{array}{c}\text { Sangat } \\
\text { Baik }\end{array}$ & 84 & $\begin{array}{c}\text { Sangat } \\
\text { Baik }\end{array}$ & 82,94 & $100 \%$ \\
\hline
\end{tabular}


Berdasarkan data di atas, dapat diketahui bahwa indikator keberhasilan penelitian yaitu nilai rata-rata seluruh siswa masuk kategori tinggi atau lebih dari 80 telah tercapai pada siklus kedua. Hal itu dikarenakan pembelajaran kontekstual memungkinkan siswa mengubungkan isi mata pelajaran akademik dengan konteks kehidupan sehari-hari untuk menemukan makna. Pembelajaran kontekstual memperluas konteks priibadi siswa lebih lanjut melalui pemberian pengalaman segar yang akan merangsang otak guna menjalin hubungan baru utuk menemukan makna yang baru.

Selain itu, terjadinya peningkatan keberhasilan pada siklus II dikarenakan dalam model pembelajaran kontekstual terdapat prinsip-prinsip yang dapat meningkatkan kemampuan siswa dalam mengikuti proses pembelajaran. Prinsip-prinsip tersebut antaranya ialah prinsip pertama ialah konstruktivisme yang merupakan landasan berpikir dalam pembelajaran kontekstual, yaitu bahwa pengetahuan dibangun oleh manusia sedikit demi sedikityang hasilnya diperluas melalui konteks yang terbatas. Pengetahuan bukanlah seperangkat fakta, konsep atau kaidah yang siap untuk diambil dan diingat. Manusia harus membangun pengetahuan itu memberi makna melalui pengalaman yang nyata. Batasan konstruktivisme di atas memberikan penekanan bahwa konsep bukanlah tidak penting sebagai bagian integral dari pengalaman belajar yang harus dimiliki oleh siswa, akan tetapi bagaimana dari setiap konsep atau pengetahuan yang dimiliki siswa itu dapat memberikan pedoman nyata untuk diaktualisasikan dalam kondisi nyata. Kemudian prinsip kedua ialah menemukan. Menemukan merupakan kegiatan inti dari pembelajara kontekstual, melalui upaya meemukan akan memberikan penegasan bahwa pengetahuan dan keterampilan serta kemampuan-kemampuan lain yang diperlukan bukan merupakan hasil mengingat seperangkat fakta-fakta, tetapi merupakan hasil menemukan sendiri (Putra, 2017).

Prinsip selanjuntnya dalam pembelajaran kontekstual adalah kemampuan dan kebiassaan bertanya. Pengetahuan yang dimiliki seseorang selalu bermula dari bertanya. Oleh karena itu, bertanya merupakan strategi utama dan pembelajaran kontekstual. Penerapan unsur bertanya dalam pembelajaran kontekstual harus difasilitasi oleh guru, kebiasaan siswa untuk bertanya atau kemampuan guru dalam menggunakan pertanyaan yang baik akan mendorong pada peningkatan kualitas dan produktivitas pembelajaran. Berkembangnya kemampuan dan keinginan untuk bertanya sangat dipengaruhi oleh suasana kegiatan pembelajaran yang dikembangkan oleh guru. Pertanyaan yang diajukan oleh guru atau siswa harus dijadikan alat untuk menggali informai atau sumber yang ada kaitannya dengan kehidupan nyata. Dengan kata lain, tugas bagi guru adalah membimbing siswa melalui pertanyaan yang diajukan untuk mencari dan menemukan kaitan antara konsep yang dipelajari dengan kehidupan nyata. Prinsip selanjutnya adalah masyarakat belajar yang maksudnya adalah membiasakan siswa untuk melakukan kerja sama dan memanfaatkan sumber belajar dari teman belajarnya. Seperti yang disarankan pada learning community bahwa hasil belajar diperoleh dari hasil kerja sama dengan orang lain melalui berbagai pengalaman (Sharing). Melalui sharing ini anak dibiasakan utuk saling memberi dan menerima dari teman belajarnya.

Prinsip lainnya ialah guru bukan satu-satunya sumber belajar bagi siswa, karena dengan segala kelebihan dan keterbatasan yang dimiliki oleh guru akan mengalami hambatan untuk memberikan pelayanan sesuai dengan kebutuhan siswa yang heterogen. Oleh karena itu, tahap pembuatan model dapat dijadikan alternatif untuk mengembangkan pembelajaran dan mengatasi keterbatasan yang dimiliki oleh para guru. Prinsip selanjutnya ialah refleksi. Refleksi adalah cara berpikir tentang apa yang baru terjadi atau baru dipelajari. Dengan kata lain refleksi adalah berpikir ke belakang tentang apa-apa yang sudah dilakukan di masa lalu, siswa mengendapkan apa yang sudah dipelajarinya sebagai struktur pengetahuan yang baru yang merupakan pengayaan atau revisi dari pengetahuan sebelumnya.pda saat refleksi, siswa diberi kesempatan utuk mencerna, menimbang, membandingkan, menghayati, dan 
melakukan diskusi dengan dirinya sendiri. Prinsip terakhir pembelajaran kontekstual adalah melakukan penilaian. Penilaian sebagai bagian integral dari pembelajaran memiliki fungsi yang amat menentukan untuk mendapatkan informasi kualitas dan hasil pembelajarn kontekstual. Dengan terkumpulnya berbagai data dan informasi yang lengkap sebagai perwujudan dari penerapan penilain, maka akan semakin akurat pula pemahaman guru terhadap proses dan hasil pengalaman belajar siswa.

Semua prinsip yang dijabarkan di atas merupakan hal-hal yang dilakukan Ketika kita menerapkan model pembelajaran kontekstual. Semua prinsip tersebut dilakukan sehingga dapat membuat suasana kelas menjadi menyenangkan dan siswa dapat berperan aktif dalam proses pembelajaran. Dampak dari itu semua yakni hasil belajar siswa dapat meningkat. Model pembelajaran kontekstual cocok diterapkan dikarenakan memiliki banyak kelebihan diantaranya ialah (1) pembelajaran kontekstual dapat meningkatkan aktivitas berpikir siswa seara penuh baik fisik maupun mental, (2) pembelajara kontekstual dapat menjadikan siswa belajar bukan dengan menghafal, melainkan proses berpengalaman dalam kehiduan nyata, (3) kelas dalam kontekstual bukan tempat untuk memperoleh informasi, melainkan sebagai tempat untuk menguji data hasil temuan mereka di lapangan, (4) materi pelajaran dikonstruksi oleh siswa sendiri (Luh Rai, 2019; Miryani et al., 2020).

Hasil penelitian ini juga didukung oleh penelitian relevan seperti yang dilakukan oleh (Rahayu, 2019) yang menemukan bahwa pengggunaan model pembelajaran Kontekstual yang dilaksanakan sesuai skenario dapat meningkatkan hasil belajar materi bangun datar pada siswa kelas III SD. Kemudian penelitian yang dilakukan oleh (Lestari, 2019) menemukan bahwa terdapat perbedaan hasil belajar Matematika antara siswa yang mengikuti pembelajaran kontekstual dengan siswa yang mengikuti pembelajaran konvensional serta terdapat kontribusi kemampuan numerik dan kemampuan verbal terhadap hasil belajar Matematika. Penelitian lain juga dilakukan dan menemukan bahwa penggunaan model pembelajaran kontekstual dapat meningkatkan hasil belajar matematika siswa kelas $5 \mathrm{SD}$ (Setiawan \& Sudana, 2018).

\section{CONCLUSION}

Model pembelajaran kontekstual dapat meningkatakan hasil belajar matematika siswa kelas V sekolah dasar dibuktikan dengan peningkatan keberhasilan pada siklus II. Diiharapakan guru mampu menggunakan model pembelajaran kontekstual secara optimal dan tidak hanya menjadikan model pembelajaran kontekstual sebagai alternatif dalam kegiatan pembelajaran, namun menjadikan model pembelajaran kontekstual sebagai pilihan utama dalam melaksanakan kegiatan belajar mengajar.

\section{REFERENCES}

Adirakasiwi, A. G., \& Warmi, A. (2018). Penggunaan Software Cabri 3D Dalam Pembelajaran Matematika Upaya Meningkatkan Kemampuan Visualisasi Spasial Matematis Siswa. JURNAL SILOGISME: Kajian Ilmu Matematika Dan Pembelajarannya, 3(1), 28. https://doi.org/10.24269/js.v3i1.972.

Arikunto, S. (2013). Dasar-Dasar Evaluasi Pendidikan. Bumi Aksara.

Azhari, B., \& Irfan, A. (2018). Model-Eliciting Activities dalam Menganalisis Kreativitas Pemecahan Masalah Matematika pada Mahasiswa Pendidikan Matematika di PTKIN Aceh. Al-Khawarizmi: Jurnal Pendidikan Dan Pembelajaran Matematika, 2(1). http://dx.doi.org/10.22373/jppm.v2i1.4495.

Lestari, N. A. P. (2019). Pengaruh Implementasi Pembelajaran Kontekstual terhadap Hasil 
Belajar Matematika dengan Kovariabel Kemampuan Numerik dan Kemampuan Verbal. Jurnal Pendidikan Dasar Nusantara, 5(1), 72. https://doi.org/10.29407/jpdn.v5i1.12845.

Luh Rai, N. (2019). Penerapan Pendekatan Kontekstual untuk Meningkatkan Hasil Belajar Matematika. Journal of Education Action Research, 3(2), 131. https://doi.org/10.23887/jear.v3i2.17269.

Mahendrawan, I. P., Suwatra, I. W., \& Suarjana, I. M. (2014). Penerapan Pendekatan Kontekstual untuk Meningkatkan Hasil Belajar Matematika Siswa Kelas V Sekolah Dasar Nomor 1 Tukadsumaga. Mimbar PGSD Undiksha, 2(1). http://dx.doi.org/10.23887/jjpgsd.v2i1.4038.

Masykur, R., Nofrizal, N., \& Syazali, M. (2017). Pengembangan Media Pembelajaran Matematika dengan Macromedia Flash. Al-Jabar: Jurnal Pendidikan Matematika, 8(2), 177. https://doi.org/10.24042/ajpm.v8i2.2014.

Miryani, A. R., Muslim, A., \& Pamujo, P. (2020). Peningkatan Prestasi Belajar Matematika melalui Pembelajaran Kontekstual di Sekolah Dasar. MUKADIMAH: Jurnal Pendidikan, Sejarah, Dan Ilmu-Ilmu Sosial, 4(1), 22-25. https://doi.org/10.30743/mkd.v4i1.1522.

Ningsih, Y. L. (2016). Kemampuan Pemahaman Konsep Matematika Mahasiswa Melalui Penerapan Lembar Aktivitas Mahasiswa (LAM) Berbasis Teori APOS pada Materi Turunan. Edumatica, 6(1), 1-8. https://doi.org/10.22437/edumatica.v6i01.2994.

Primayana, K. H., Lasmawan, W., \& Adnyana, P. B. (2019). Pengaruh Model Pembelajaran Kontekstual Berbasis Lingkungan Terhadap Hasil Belajar IPA Ditinjau dari Minat Outdoor Pada Siswa Kelas IV. Jurnal Pendidikan Dan Pembelajaran Ipa Indonesia, 9(2), 72-79. https://ejournalpasca.undiksha.ac.id/index.php/jurnal_ipa/article/view/2905/0.

Putra, F. G. (2017). Eksperimentasi Pendekatan Kontekstual Berbantuan Hands on Activity (HoA) Terhadap Kemampuan Pemecahan Masalah Matematik. Al-Jabar: Jurnal Pendidikan Matematika, 8(1), 73-80. https://doi.org/10.24042/ajpm.v8i1.1148.

Rahayu, D. P. (2019). Penggunaan Model Pembelajaran Kontekstual untuk Meningkatkan Hasil Belajar Materi Bangun Datar di Kelas III Sekolah Dasa. Musamus Journal of Primary Education, 1(2), 061-072. https://doi.org/10.35724/musjpe.v1i2.1464.

Ramdani, E. (2018). Model Pembelajaran Kontekstual Berbasis Kearifan Lokal sebagai Penguatan Pendidikan Karakter. Jupiis: Jurnal Pendidikan Ilmu-Ilmu Sosial, 10(1), 1. https://doi.org/10.24114/jupiis.v10i1.8264.

Riski Juniarti1, N. K., Margunayasa, I. G., \& Kusmariyatni, N. (2020). Hubungan Antara Pola Asuh Orang Tua dan Konsep Diri dengan Kompetensi Pengetahuan Matematika Siswa. Jurnal Ilmiah Sekolah 17. https://doi.org/10.23887/jisd.v4i1.24273.

Setiawan, P., \& Sudana, I. D. N. (2018). Penerapan Model Pembelajaran Kontekstual untuk Meningkatkan Hasil Belajar Matematika. Jurnal Ilmiah Pendidikan Profesi Guru, 1(2). http://dx.doi.org/10.23887/jippg.v1i2.16397.

Setyadi, D., \& Qohar, A. (2017). Pengembangan Media Pembelajaran Matematika Berbasis Web Pada Materi Barisan Dan Deret. Kreano, Jurnal Matematika Kreatif-Inovatif, 8(1), 1-7. https://doi.org/10.15294/kreano.v8i1.5964.

Zairisma, Z., Apriliani, V., \& Yunus, J. (2020). Mathematical Representation Ability of Middle School Students through Model Eliciting Activities with STAD Type. Desimal: Jurnal Matematika, 3(2), 109-116. https://doi.org/10.24042/djm.v3i2.5751. 